\title{
CALIX[4]ARENE C-99 INHIBITS MYOSIN ATPase ACTIVITY AND CHANGES THE ORGANIZATION OF CONTRACTILE FILAMENTS OF MYOMETRIUM
}

\author{
R. D. LABYNTSEVA', A. A. BEVZA', A. O. LUL'KO', S. O. CHERENOK', \\ V. I. KALCHENKO', S. O. KOSTERIN ${ }^{1}$ \\ ${ }^{1}$ Palladin Institute of Biochemistry, National Academy of Sciences of Ukraine, Kyiv; \\ e-mail: labyntseva@biochem.kiev.ua; \\ ${ }^{2}$ Institute of Organic Chemistry, National Academy of Sciences of Ukraine, Kiev
}

Calix[4]arenes are cup-like macrocyclic (polyphenolic) compounds, they are regarded as promising molecular "platforms" for the design of new physiologically active compounds. We have earlier found that calix[4]arene C-99 inhibits the ATPase activity of actomyosin and myosin subfragment-1 of pig uterus in vitro. The aim of this study was to investigate the interaction of calix[4]arene C-99 with myosin from rat uterine myocytes. It was found that the ATPase activity of myosin prepared from pre-incubated with $100 \mathrm{mM}$ of calix[4]arene C-99 myocytes was almost 50\% lower than in control. Additionally, we have revealed the effect of calix[4]arene C-99 on the subcellular distribution of actin and myosin in uterus myocytes by the method of confocal microscopy. This effect can be caused by reorganization of the structure of the contractile smooth muscle cell proteins due to their interaction with calix[4]arene. The obtained results demonstrate the ability of calix[4]arene C-99 to penetrate into the uterus muscle cells and affect not only the myosin ATPase activity, but also the structure of the actin and myosin filaments in the myometrial cells. Demonstrated ability of calix[4]arene C-99 can be used for development of new pharmacological agents for efficient normalization of myometrial contractile hyperfunction.

Key words: myosin, actin, myometrial myocytes, ATPase activity, calix[4]arene C-99, confocal microscopy.

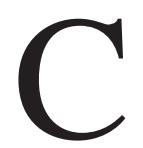

onsiderable attention has been recently given to such compounds as calixarenes in international biochemical publications. These are synthetic macrocyclic phenol oligomers, which molecules have a cup-like structure and functionalized with different chemical groups. Calixarenes, calix[4]arenes in particular, can affect biochemical processes in a cell, due to their ability to form supramolecular complexes with biologically important molecules and ions; correspondingly, they are considered as promising molecular "platforms" for the design of new physiologically active compounds $[1,2]$.

Calix[4]arene C-99 (5,17-bis(dihydroxyphosph onylmethylol)-26,28-dihydroxy-25,27-dipropoxycalix[4]arene) is a cup-like four-cycle compound with two phosphonyl groups on the upper rim (Fig. 1).

We have already shown in experiments in vitro that calix[4] arene C-99 is an efficient inhibitor of ATPase of actomyosin complex and subfragment-1 of myosin of the uterus smooth muscle $\left(\mathrm{I}_{0.5}=84 \pm 2\right.$ and $43 \pm 8 \mu \mathrm{M}$, respectively). Study of kinetic regu-

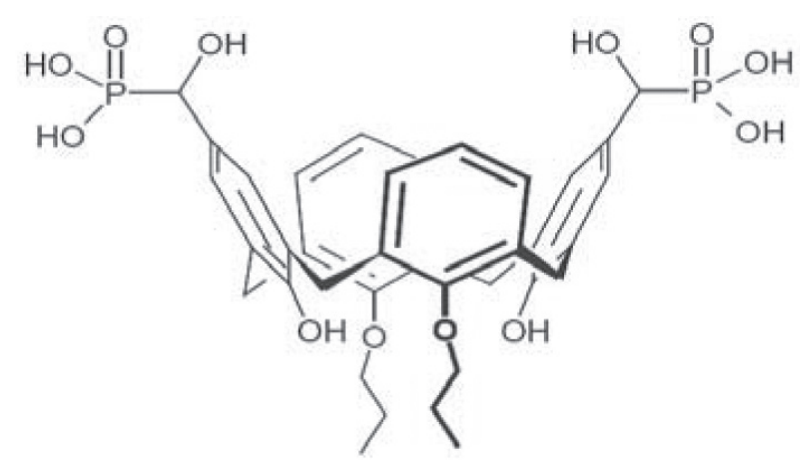

Fig. 1. Structural formula of calix[4]arene C-99

larities of this compound effect on ATP-hydrolase activity of myosin subfragment-1, namely, on the Michaelis constant $\left(K_{\mathrm{m}}\right)$, the constant of activation by magnesium cation $\left(K_{\mathrm{Mg}}\right)$ and on maximum velocity of ATP-hydrolysis process that is catalyzed by myosin subfragment-1, in respect of ATP $\left(V_{\max , \mathrm{ATP}}\right)$ and $\operatorname{Mg}^{2+}\left(V_{\max , \mathrm{Mg}}\right)$, has shown that calix[4]arene C-99 inhibits the process of ATP hydrolysis noncompetitively with respect to its substrate. This compound 
decreases the number of catalytic turns of myosin subfragment- 1 both in respect of ATP and $\mathrm{Mg}^{2+}$. The increase of hydrodynamic diameter of myosin subfragment-1 in the presence of calix[4]arene C-99 points indirectly to the complex formation between this substance and the above mentioned calix[4]arene [3]. It is also established that calix[4]arene C-99 is an efficient inhibitor of enzymatic activity of $\mathrm{Na}^{+}, \mathrm{K}^{+}$-ATPase of plasmatic membrane (PM) $\left(\mathrm{I}_{0.5}<100 \mathrm{nM}\right)$, having practically no effect on activity of $\mathrm{Mg}^{2+}$-ATPase of PM [4].

The calix[4]arene C-99 ability to inhibit ATPase activity of contractile myometrium proteins, as well as activity of $\mathrm{Na}^{+}, \mathrm{K}^{+}$-ATPase of PM of the uterine smooth muscles may be further used for elaboration of new pharmacologic agents capable of efficient recovery of the normal uterus contractile function under pathologic states of the myometrium. Since the above experiments were carried out on isolated enzymes or on membrane vesicles, i. e., not on the cell level, it is very important to investigate the ability of calix[4]arene C-99 to penetrate through PM inside the uterine smooth muscle cells.

The aim of our work was to study the interaction of calix[4]arene C-99 with a contractile complex of smooth muscles on the model of isolated uterine myocytes. Since the isolated uterine smooth-muscle cells were foreseen to be used as the main object of research it was necessary, first of all, to adapt known protocols of isolation and cultivation of the primary culture of myocytes to our investigations $[5,6]$. Isolation of a homogeneous population of uterine smooth-muscle cells is considerably complicated because other uterine cells, including fibroblasts [6], which are visually similar to myocytes and contain non-muscular myosin and actin, are isolated jointly with the smooth muscle uterine cells (myometrium). Thus, it was necessary to develop an approach, which could give a possibility to analyze localization of contractile proteins exceptionally in uterine myocytes. Hence, we had proposed an approach, which consisted in dual staining of cell samples with fluorescently labeled antibodies against smooth muscle $\alpha$-actin and myosin II. It is known that myosin II is expressed not only in smooth myocytes, but also in other cells, while $\alpha$-actin is a specific marker of smooth muscle cells [7], that is why the approach of dual staining permitted us to analyze the effect of calix[4]arene C-99 on myosin II of only smooth muscle cells, which were stained simultaneously for $\alpha$-actin. For this purpose, we have developed a protocol for staining myosin and actin in the uterine smooth muscle cells with fluorescently labeled antibodies against myosin II and smooth muscle $\alpha$-actin under conditions of preincubation of native cells with calix[4]arene C-99 and in control (without C-99), and their localization in myocyte was investigated by the method of confocal microscopy.

\section{Materials and Methods}

The following reagents produced by Sigma company (USA) were used in the work: culture medium RPMI-1640 with L-glutamine, nutrient medium DMEM F-12 with L-glutamine and 15 mM HEPES without sodium bicarbonate, mixture of antibiotics (penicillin and streptomycin) and antimycotic (amphotericin) solutions, monoclonal antibodies against smooth muscle $\alpha$-actin, antibodies against myosin II, FITC-conjugated secondary antibodies against Fcfragmens of mouse antigen, FITC-conjugated secondary antibodies against $\mathrm{Fc}$-fragmens of rabbit antigen, Alexa 594-conjugated secondary antibodies against $\mathrm{Fc}$-fragmens of mouse antigen, bovine serum albumin (BSA), MTT reagent (3-(4,5-dimethylthiazolyl-2)-2,5-diphenyltetrazolium bromide), PBS (phosphate-buffered saline: $0.8 \% \mathrm{NaCl}, 0.02 \% \mathrm{KCl}$, $0.144 \% \mathrm{Na}_{2} \mathrm{HPO}_{4}, 0.024 \% \mathrm{KH}_{2} \mathrm{PO}_{4}, \mathrm{pH} 7.4$ ), medium for cells fixation based on polyvinyl alcohol (Polyvinyl alcohol mounting medium with DABCO), DMSO, SDS, collagenase 1 of A-type, Trypsin inhibitor from Glycine max (soybean), poly-L-lysine; Fetal Bovine Serum (Gold, EU-approved).

Calix[4]arene C-99 was synthesized in the Department of Phosphoranes Chemistry of NAS of Ukraine headed by V. I. Kalchenko, Corr. Member of NAS of Ukraine. $1 \mathrm{mM}$ stock solution of calix[4]aren C-99 was prepared in $50 \mathrm{mM}$ Tris- $\mathrm{HCl}$, $\mathrm{pH}$ 7.2.

A confocal microscope Carl Zeiss LSM 510 Meta (Carl Zeiss, Germany), ESCO laminar cabinets of biosafety level II (Singapore), centrifuge MLW T23D (ELMI, Germany), device for vertical electrophoresis Mini-Protein II Electrophoretic Cell (Bio-Rad, USA) were used in the experiment.

Confocal microscopy of isolated cells. Myocyte suspension of the nonpregnant rat uterus was obtained using type $1 \mathrm{~A}$ collagen and soybean trypsin inhibitor by Gangula method [5]. The female rat uterus was thoroughly purified and dissociated in Hank's solution in the presence of $\mathrm{Ca}^{2+}$ and $\mathrm{Mg}^{2+}$ $\left(136.9 \mathrm{mM} \mathrm{NaCl}, 5.36 \mathrm{mM} \mathrm{KCl}, 1.26 \mathrm{mM} \mathrm{CaCl}_{2}\right.$, $0.44 \mathrm{mM} \mathrm{KH} \mathrm{PO}_{4}, 0.26 \mathrm{mM} \mathrm{Na}_{2} \mathrm{HPO}_{4}, 4.5 \mathrm{mM}$ 
$\mathrm{NaHCO}_{3}, 0.4 \mathrm{mM} \mathrm{MgCl}{ }_{2}, 5 \mathrm{mM}$ glucose, $0.4 \mathrm{mM}$ $\mathrm{MgSO}_{4}, 10 \mathrm{mM}$ HEPES, $\mathrm{pH} 7.4$ at $37^{\circ} \mathrm{C}$ ). The uterus pieces were washed in Hank's solution without $\mathrm{Ca}^{2+}$ and $\mathrm{Mg}^{2+}$, and cells were dissociated in solution which contained $0.1 \%$ collagenase $1 \mathrm{~A}$ and $0.01 \%$ trypsin inhibitor from Glycine max (soybean). Dissociated cells were precipitated by centrifugation at $80 \mathrm{~g}$, suspended in $10 \mathrm{mM}$ HEPES, $\mathrm{pH}$ 7.4, which contained $150 \mathrm{mM} \mathrm{NaCl}$, to concentration $5-8 \times 10^{6}$ cells $/ \mathrm{ml}$. Myocyte suspension aliquots in $10 \mathrm{mM}$ HEPES, pH 7.4, with $150 \mathrm{mM} \mathrm{NaCl}$, which contained about 1 million cells, were applied on cover glass coated with poly-L-lysine for 1-2 $\mathrm{h}$. The cover glasses were pretreated with $1 \mathrm{~N} \mathrm{HCl}$ at $50-60{ }^{\circ} \mathrm{C}$ for 8-16 h to improve cell adhesion. Cover glasses were washed with PBS/BSA (PBS adding $1 \% \mathrm{BSA}$ ) to remove unbound cells. Myocytes were fixed with $4 \%$ paraformaldehyde and permeabilized using $0.05 \%$ triton X-100 for $40 \mathrm{~min}$ at $4{ }^{\circ} \mathrm{C}$. Myocytes were incubated in $100 \mu \mathrm{M}$ calix[4] arene C-99 in PBS for $1 \mathrm{~h}$ with following PBS/BSA washes (5 times). After that cover glasses were prepared for confocal microscopy (see further). The control cells were incubated under the same conditions in PBS with adding a buffer for dilution of calix[4]arene.

Cultivation of primary myocyte cells. All procedures for obtaining cultivated myocytes were performed in sterile conditions under a laminar flow using collagenase 1 of A type. The cells were cultivated in RPMI-1640 or DMEM F-12 nutrient medium with mix of antibiotics (penicillin $1000 \mathrm{U} / \mathrm{ml}$, streptomycin $100 \mu \mathrm{g} / \mathrm{ml}$ ) and an antimycotic (amphotericin B $0.25 \mu \mathrm{g} / \mathrm{ml}$ ), and 20\% Fetal Bovine Serum at $37{ }^{\circ} \mathrm{C}$ at $5 \% \mathrm{CO}_{2}$ concentration in the atmosphere (standard conditions). Cells were placed on cover glasses in the wells of a 24-well plate and cultivated in standard conditions for 1-2 days to ensure the attachment and spreading of the cells. The cells were washed with PBS before adding calix[4]arene C-99. The medium was changed by serum-free one with 25 or $100 \mu \mathrm{M}$ calix[4]arene C-99. After that, cells were cultivated for $1 \mathrm{~h}$ in standard conditions. The control cells were incubated in the same conditions but calix[4]arene was replaced by its buffer for dissolving.

Confocal microscopy of cultivated cells. The cells attached to cover glasses were stained for $\alpha$-actin and myosin by incubation with FITC-labeled monoclonal antibodies against smooth muscle $\alpha$-actin and FITC- or Alexa 594-labeled antibodies against myosin II for $60 \mathrm{~min}$ at $37{ }^{\circ} \mathrm{C}$. Hoechst
33342 was used as a dye for nuclei staining. Cover glasses with cells were mounted on a slide in the polyvinyl alcohol based medium for cell mounting. Preparations were analyzed on confocal microscope Carl Zeiss LSM 510 Meta (Carl Zeiss, Germany). The image was obtained using $63 \times$ immersion lens (Plan-Achromat 63×/1.4 Oil DIC) from three channels, which register fluorescence of Hoechst 33342 (BP 420-480), FITC (BP 505-530) and Alexa 594 (LP 560), the exciting lasers were of 405, 488 and $582 \mathrm{~nm}$, respectively.

MTT proliferative assay. Cells were grown to confluent state on 96-well plates to perform MTT proliferative assay. The cells were washed with PBS before adding calix[4]arene C-99. The medium was changed by serum-free one with concentration from 6 to $500 \mu \mathrm{M}$ calix[4]arene. Then, the cells were cultivated for $24 \mathrm{~h}$ in standard conditions. The control cells were incubated in the analogous conditions in PBS without adding calix[4] arene C-99. Further, the content of the wells with cells was substituted by a new nutrient medium with $0.5 \mathrm{mg} / \mathrm{ml}$ solution of MTT reagent and incubated for $4 \mathrm{~h}$ at $37^{\circ} \mathrm{C}$, which led to transformation of water-soluble MTT onto insoluble violet formazan crystals. Formazan was solubilized with the aid of $10 \%$ SDS and $0.6 \%$ acetic acid in DMSO for 5 min under intensive shaking [8]. Formazan concentration was determined by the solution optical absorption at $545 \mathrm{~nm}$ (assay) and $630 \mathrm{~nm}$ (comparison) on $\mu$ Quwant plate reader (Biotek Instruments, Inc., USA).

Isolation of myosin. Myosin was obtained from rat uterus myocytes, using the developed micromethod, which allowed receiving such amount of myosin $(800 \mathrm{mg})$ from one uterus, which is sufficient for determining its ATPase activity (10-20 $\mu \mathrm{g}$ of protein in a sample). Experimental cells were preliminarily incubated with $100 \mathrm{mM}$ calix[4]arene C-99 in $10 \mathrm{mM}$ HEPES, $\mathrm{pH}$ 7.4, which contained $150 \mathrm{mM}$ $\mathrm{NaCl}$ during $1 \mathrm{~h}$, at the same time, native myocytes were incubated under the same conditions in the same buffer but without calix[4]arene. After washing step, the cells were frozen in liquid nitrogen and kept in a freezer at $-80{ }^{\circ} \mathrm{C}$. The next day the cells were thawed and myosin was extracted from them with a buffer, which contained $0.6 \mathrm{M} \mathrm{KCl}, 10 \mathrm{mM}$ tris$\mathrm{HCl}(\mathrm{pH} 7.5), 1 \mathrm{mM}$ sodium azide, $0.5 \mathrm{mM}$ phenylmethylsulphonylfluoride, $0.3 \mathrm{mM}$ dithiothreitol. The cell residue was separated by centrifugation at $1600 \mathrm{~g}$, following myosin extraction. The precipitate liquid was 10 -fold diluted with cold water for myo- 
sin precipitation and purification from water-soluble proteins. Myosin was precipitated by centrifugation at $10000 \mathrm{~g}$ by MLWT23D centrifuge (ELMI, Germany), and the precipitate was diluted in minimum amount of $50 \mathrm{mM}$ Tris-HCl buffer ( $\mathrm{pH}$ 7.2) with $0.6 \mathrm{M} \mathrm{KCl}$. The preparation purity was examined by PAGE in denaturing conditions [9]. Myosin ATPase activity was measured at $37{ }^{\circ} \mathrm{C}$ in $1 \mathrm{ml}$ of incubation medium containing $3 \mathrm{mM}$ ATP, $5 \mathrm{mM} \mathrm{MgCl}_{2}$, $0.010 \mathrm{mM} \mathrm{CaCl}_{2}, 100 \mathrm{mM} \mathrm{KCl}, 20 \mathrm{mM}$ Tris-HCl ( $\mathrm{pH}$ 7.2). The amount of $\mathrm{P}_{\mathrm{i}}$ released in the reaction of ATP hydrolysis was determined by the method of Chen [10].

\section{Results and Discussion}

Study of calix[4]arene C-99 effect on viability of uterine cells. The effect of calix[4]arene C-99 on ATPase activity of myometrial contractile proteins and activity of $\mathrm{Na}^{+} / \mathrm{K}^{+}$-ATPase of PM of the uterine smooth muscles was studied on the model of PM vesicles and on isolated proteins [3, 4]. It was necessary to determine the cytotoxicity of this compound and effect of calix[4]arene C-99 on uterine myocytes for further experiments in the presence of such concentrations of calix[4] arene C-99, which would not be toxic for cells.

MTTassay was used to study the effect of calix[4] arene C-99 on viability of the uterine cells. It is based on the ability of mitochondrial dehydrogenas- es of respirating actively cells to convert water-soluble 3-(4,5-dimethylthiazol-2-yl)-2,5-diphenyltetrazolium bromide (MTT) into insoluble violet formazan, which is crystallized inside the cell. Formazan solubilization with the use of dimethylsulfoxide (DMSO) and the further photometry permits us to compare exact changes in the solution absorption as to the control with a change of the number of viable cells, and to estimate the cell death induced by one or another cytotoxic agent in cytotoxic research [8].

As a result of the performed MTT-assay, it was determined (Fig. 2) that calix[4]arene C-99 added to the uterine cell culture in concentrations from 6 to $125 \mu \mathrm{M}$ did not affect the uterine cell viability. The death of almost $40 \%$ of cells was observed in further increasing of calix[4]arene C-99 concentration to $250 \mu \mathrm{M}$ and almost $60 \%$ of uterine cells died under calix[4] arene C-99 concentration $500 \mu \mathrm{M}$. The obtained results allowed us to choose calix[4]arene C-99 concentrations of 25 and $100 \mu \mathrm{M}$ for further study, at which cells would not lose their viability.

Study of calix[4]arene C-99 ability to penetrate into cells and to affect myosin localization. To study calix[4]arene C-99 ability to penetrate into cells, the suspension of native rat uterus myocytes were preincubated with $100 \mathrm{mM}$ calix[4]arene C-99. The cells were thoroughly washed after incubation; myosin was isolated from them and its ATPase activity was determined. It appeared that myosin obtained

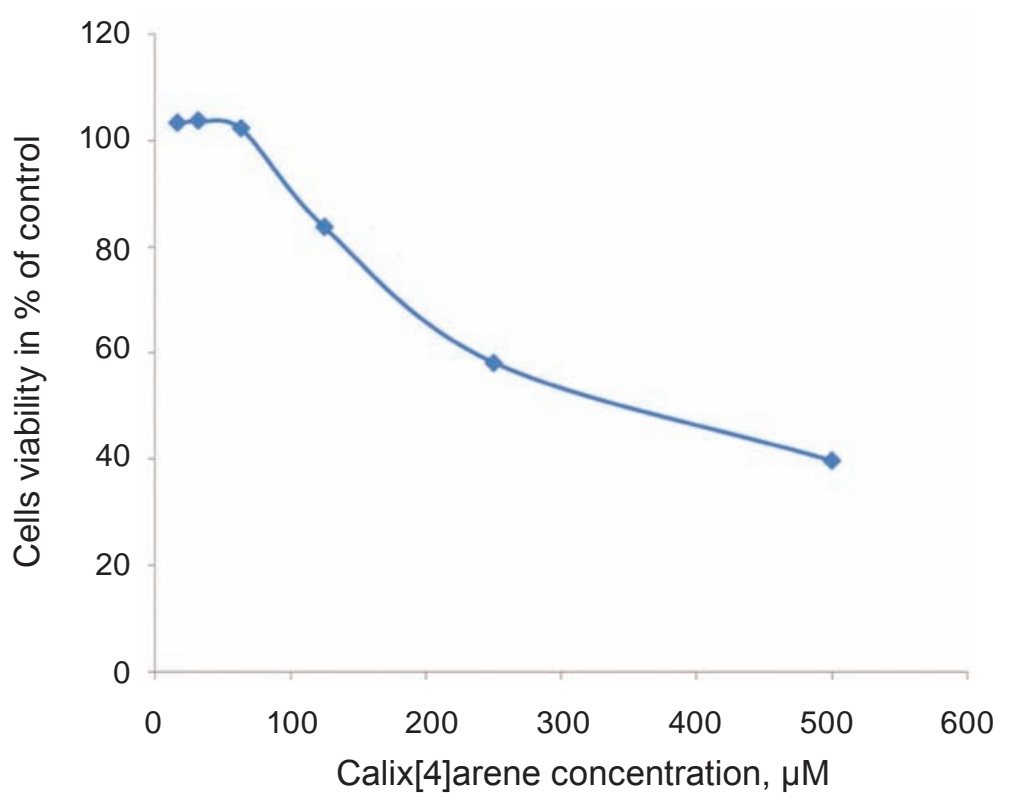

Fig. 2. Effect of calix[4]arene on viability of the uterine cells by results of MTTassay. A standard diagram of samples $(n=4)$ 
from the cells preincubated with calix[4]arene C-99 had almost twice lower ATPase activity compared to the control cells incubated in the same conditions without calix[4]arene (Fig. 3). The value of enzymatic activity of myosin obtained from such cells is close to that, determined in the in vitro experiments, when calix[4]arene C-99 was added directly to myosin, namely to its catalytic region- subfragment-1 [3]. The obtained results can be the evidence for calix[4]arene C-99 ability to penetrate into native uterus cells and to interact directly with contractile proteins.

We decided to study at the first stage how this compound affects myosin localization in myocytes to test the ability of calix[4]arene C-99 to penetrate into the native uterus cells. The experiments were carried out on uncultivated cells. Myocyte suspension was incubated for $1 \mathrm{~h}$ at $37{ }^{\circ} \mathrm{C}$ in the medium, which contained $100 \mu \mathrm{M}$ of calix[4]arene C-99, after that the cells were adhered to cover glasses with poly-L-lysine, fixed and permeabilized with $4 \%$ paraformaldehyde and $0.05 \%$ triton X-100; myosin in myocytes was visualized with FITC-labeled antibodies against myosin II. The control cells were incubated and treated to obtain preparations on cover glasses in analogous conditions, but the buffer was added instead of calix[4]arene. Myosin localization in control cells and in those preincubated with calix[4]arene C-99 was analyzed using the confocal microscope Carl Zeiss LSM 510 Meta.

Myosin II in control cells is located near the cell PM, that is agreed with published data (Fig. 4). We have found the differences in myosin structure in the uterus myocytes comparing the confocal photographs of the control and experimental myocytes. Myosin from the experimental cells preincubated with calix[4]arene C-99 had more discrete location

\section{Control}

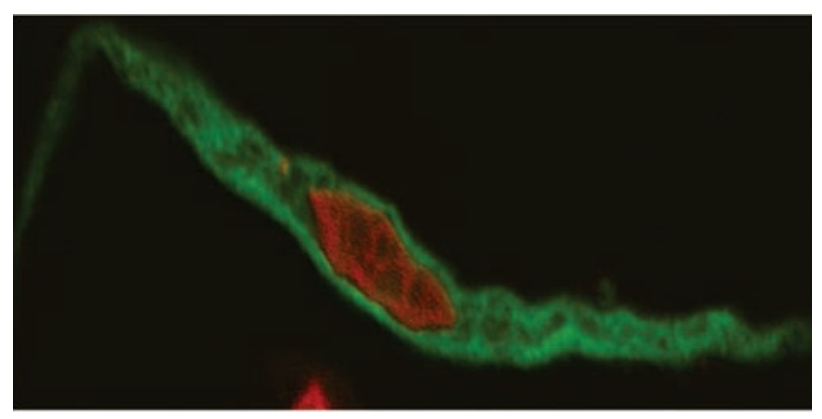

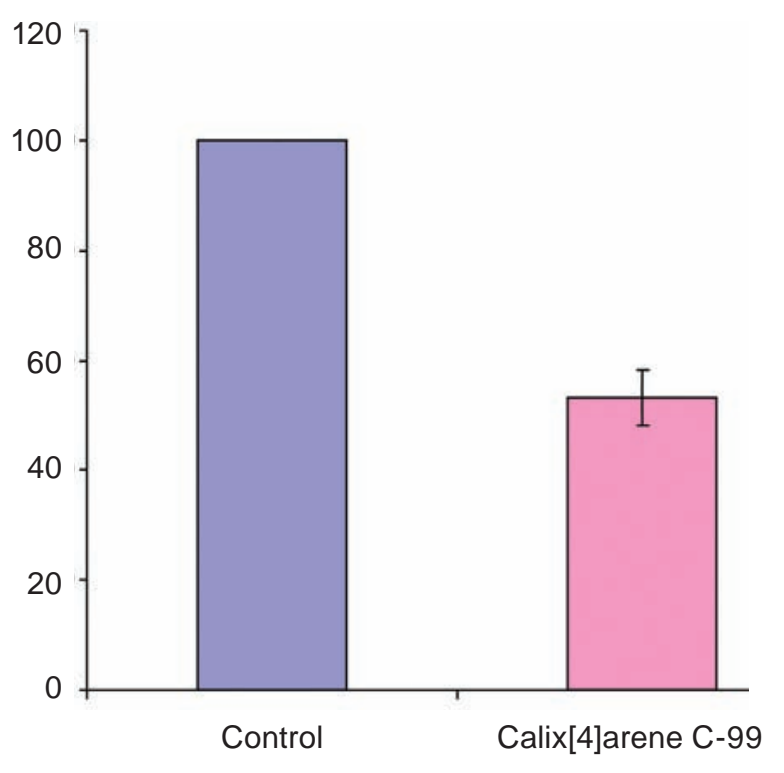

Fig. 3. ATPase activity of myosin, isolated from the suspension of rat uterus cells, in control and in conditions of myocyte suspension preincubation with $100 \mu M$ calix[4]arene C-99 ( $M \pm m, n=5)$. The value of activity in the absence of calix[4]arene $(P<0,05)$ was taken as $100 \%$ (control)

in contrast to the cells without adding calix[4]arene C-99, in which stained myosin apparently has more integrated structure. The differences of subcellular distribution of myosin in uterine myocytes in conditions of intact cells incubation with calix[4]arene C-99 compared to the control may be caused by changes in the structure of the proteins of contractile apparatus of the smooth muscle cells as a result of its interaction with calix[4]arene penetrating into cells.

The influence of calix[4]arene C-99 on myosin localization has been studied on isolated uterine cells which, when affected by calix[4]arene, were in

\section{Calix[4]arene C-99}

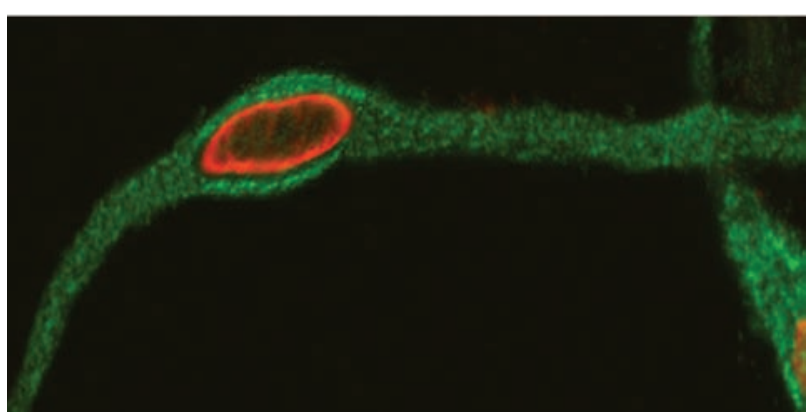

Fig. 4. Standard confocal photographs of fixed samples of rat uterus myocyte suspension stained with FITClabeled antibodies against myosin II, in control and in the presence of $100 \mu$ M calix[4]arene C-99 
the suspension that did not meet their physiological condition. At the same time, the results obtained do not guarantee any specificity of calix[4]arene effect on the SM cell myosin, since the SM cell marker was not used.

That is why, the next stage was the investigation of calix[4]arene C-99 influence on localization of contractile proteins on cultivated cells that allowed us to create conditions for cells adhesion, proliferation and growth. In our opinion, the investigation on a model of cultivated cells permits visualizing the effect of calix[4]arene C-99 on the structure of actomyosin complex of live cells in the conditions optimally close to physiologic state. The experiments were conducted on the culture of uterine myocytes, which were passaged no more than 5-6 times from the moment of isolation that was necessary to keep cells in a phase of exponential growth and to prevent their aging. The samples for confocal microscopy were prepared from myocytes adhered to cover glasses, as it was described for myocytes suspension. Actin was visualized by incubation of fixed and permeabilized cells with FITC-labeled monoclonal antibodies against smooth muscle $\alpha$-actin, which is a marker of SM cells [7].

Partial loss of the filament structure of actin and appearance of its dispersed coloring (Fig. 5) was noticeable in the experimental cells, which were incubated with $25 \mu \mathrm{M}$ calix[4]arene C-99. It was observed virtually complete relocalization of actin upon increasing of calix[4]arene C-99 concentration to $100 \mu \mathrm{M}$, namely complete loss of ac- tin filaments and diffuse (discrete) coloring. Actin filaments, located mainly lengthwise in myocytes, were well noticed on confocal photographs in control cells which were not incubated with calix[4]arene C-99. Thus, under previous incubation of myocytes with calix[4]arene C-99 $\alpha$-actin undergoes structural changes in a cell: it can be observed a gradual loss of integrity of $\alpha$-actin filaments [5].

We have studied actin and myosin colocalization in cultivated myocytes preincubated with calix[4]arene C-99 to establish specific effect of calix[4]arene C-99 on myosin of the uterus SM cells compared to the control cells. For confocal microscopy, the cultivated cells adhered to cover glasses were fixed and permeamilized, after that they were stained to reveal the presence of $\alpha$-actin and myosin by incubation with FITC-labeled antibodies against SM $\alpha$-actin and Alexa 594-labeled antibodies against myosin II. This approach allowed us to analyze the influence of calix[4]arene C-99 on myosin of SM cells, because myosin localization was mainly studied in the cells, which were stained simultaneously with fluorescently labeled antibodies against $\alpha$-actin, specific to SM cells.

An analysis of confocal images of the fixed uterus myocytes, grown in the culture and preincubated with calix[4] arene $\mathrm{C}-99$ for $1 \mathrm{~h}$ at $37^{\circ} \mathrm{C}$, has also revealed a difference in distribution and structurization of myosin and $\alpha$-actin compared to the control. $\alpha$-Actin and myosin have been visualized in a form of filaments in the control cells incubated with adding a buffer for calix[4]arene. $\alpha$-Actin and
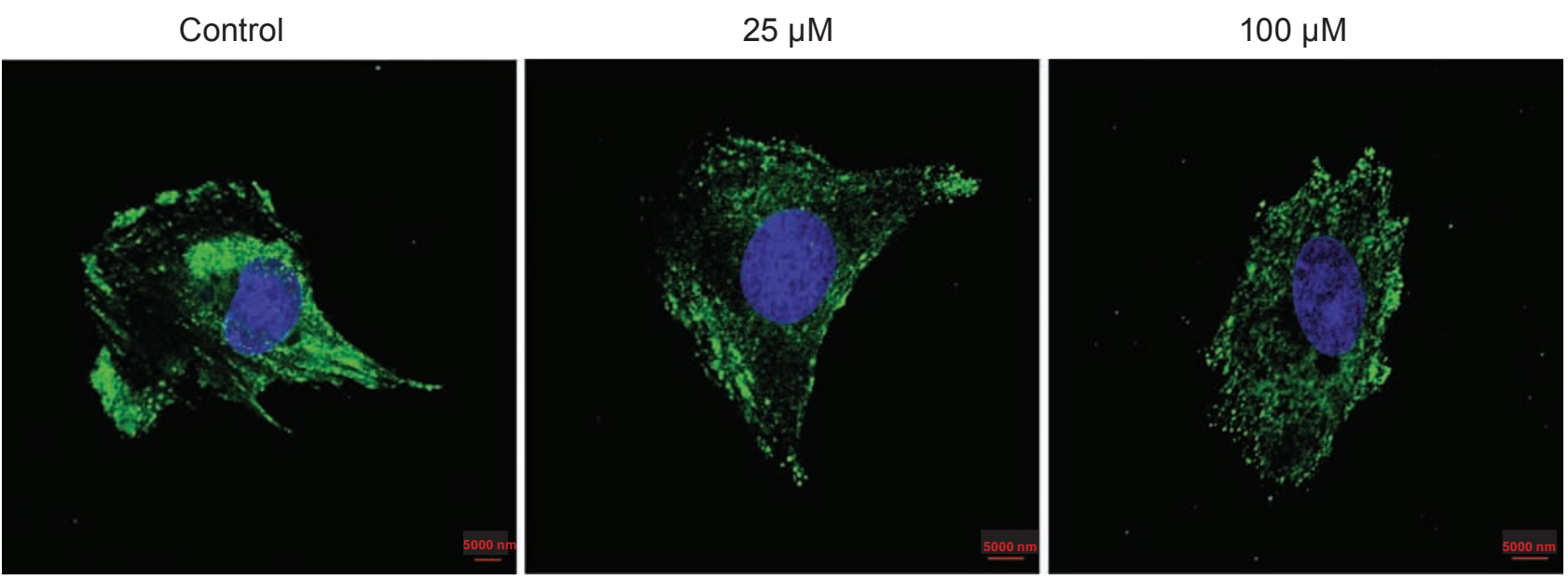

Fig. 5. Standard confocal images of fixed samples of rat uterine myocytes stained by monoclonal antibodies against smooth muscle $\alpha$-actin and secondary FITC-labeled antibodies: in control and under preincubation of myocytes with 25 and $100 \mu M$ calix[4]arene C-99 


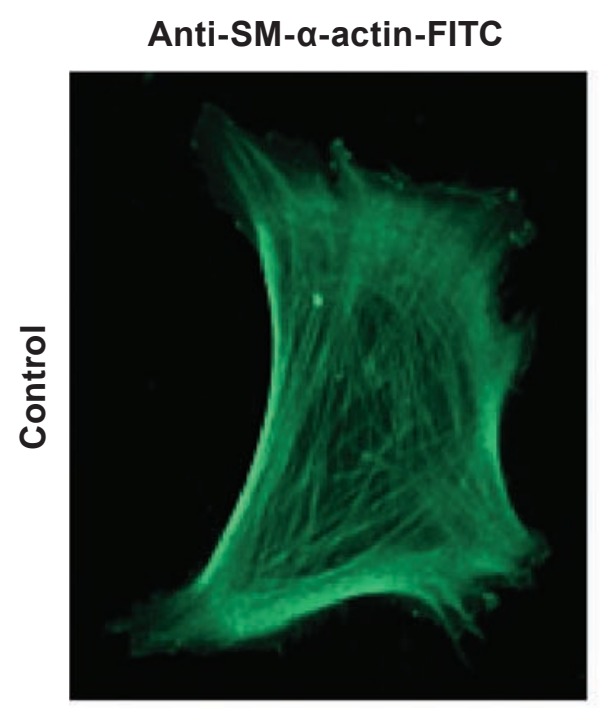

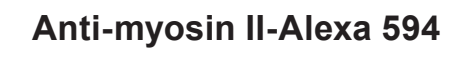
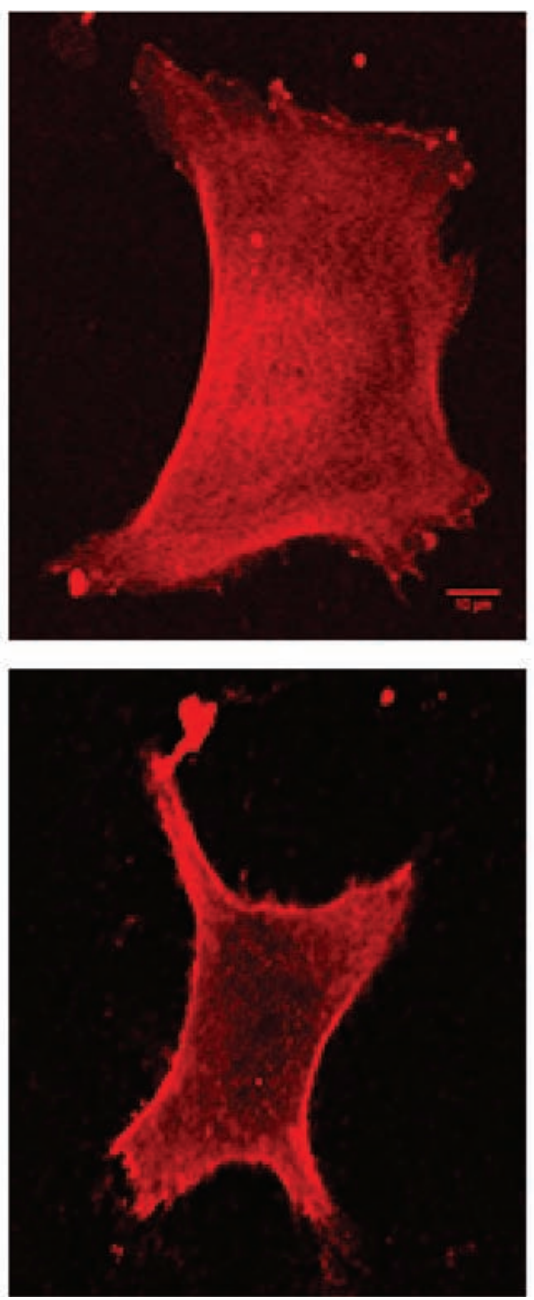

Merged
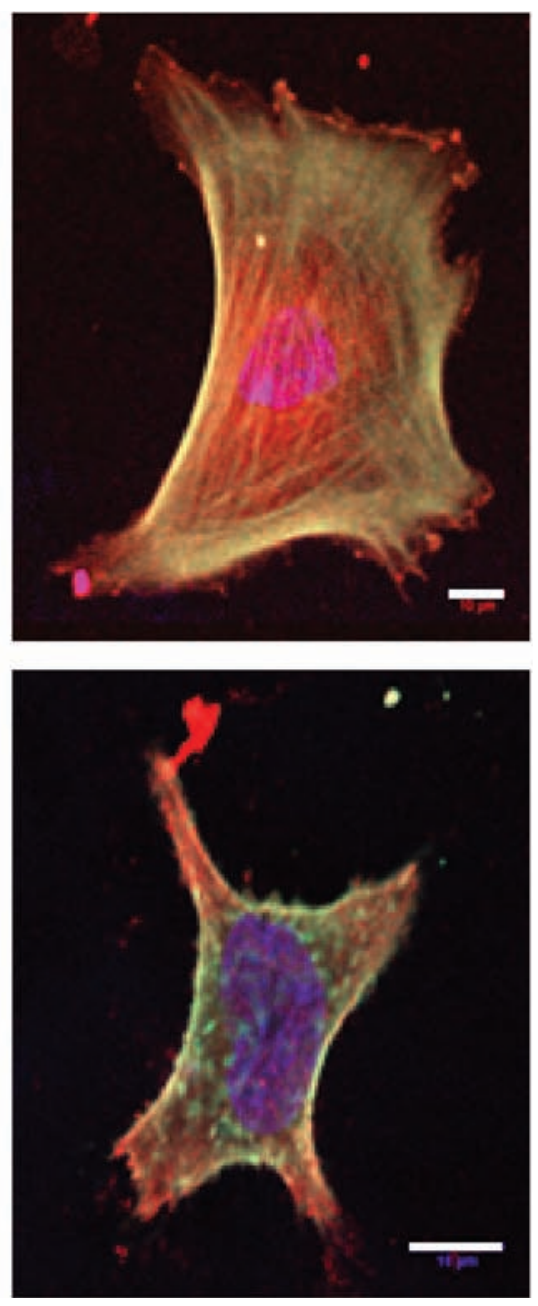

Fig. 6. Colocalization of FITC-labeled antibodies against smooth muscle $\alpha$-actin (green) and Alexa 594-marked antibodies against myosin II (red) in cultivated myocytes of myometrium - in control and in the presence of $100 \mu$ M calix[4]arene C-99

myosin lost their filament structure and looked like discrete particles in experimental myocytes preincubated with calix[4]arene C-99 (Fig. 6).

It could be supposed that synchronism in the changes of $\alpha$-actin and myosin localization in uterine myocytes is a result of associated and coordinated function of two contractile proteins in the muscle cells. The differences (compared to control) in the subcellular distribution of myosin and actin in uterus myocytes in conditions of incubation of intact cell with calix[4]arene C-99 have been found by the method of confocal microscopy. These differences may be a result of calix[4] arene penetration into a cell and its interaction with contractile proteins. The ability of calix[4]arenes to penetrate inside the cell was shown by other authors using fluorescent derivatives of some calix[4]arenes [11, 12].
Similar results concerning the effect of some compounds on the integrity of actomyosin complex have been described in published data. In particular, the ability of tapsigargin [13] and phorbol ester [14] to affect actin and myosin association was shown by the method of confocal microscopy on the culture of A7r5 SM cells; that is accompanied by transformation of actin filaments into discrete peripheral corpuscles and by diffuse localization of myosin. Such effect is a result of penetration of these compounds to A7r5 cell cytoplasm.

Therefore, we have shown the calix[4]arene C-99 ability to penetrate through PM of the uterus SM cells and to affect not only ATPase activity of myosin, but also the integrity of actomyosin complex. The obtained results opened new potentialities of using calix[4]arene C-99 as a modulator of 
contractile activity of SM cells both on the cell and organism level.

The calix[4]arene C-99 properties to penetrate into the uterus myocyte and to influence the ATPase activity of myosin and structural organization of actomyosin complex may be further used for design of new pharmacologic agents, which can recover the normal contractile function of the uterus in case of the myometrial pathology.

Acknowledgement. The authors are grateful for practical and consultative aid rendered in the process of performing this work to the employees of the Laboratory of Immunobiology at the Department of Molecular Immunology of Palladin Institute of Biochemistry Junior Research Scientist N. V. Korotkevich and Junior Research Scientist A. J. Labyntsev, and Prof. L. B. Drobot, Dr Sci. (Biol.), Head of the Laboratory of Cellular Signal Mechanisms.

\section{КАЛІКС[4]АРЕН С-99 ІНГІБУС АТРазну АКТИВНІСТЬ МІОЗИНУ ТА ЗМІНЮЄ СТРУКТУРНУ ОРГАНІЗАЦІЮ СКОРОТЛИВИХ ФІЛАМЕНТІВ МІОМЕТРІЯ}

\author{
Р. Д. Лабиниева ${ }^{1}$, А. А. Бевза ${ }^{1}$, А. О. Люлько ${ }^{1}$, \\ С. О. Черенок ${ }^{2}$ В. І. Кальченко ${ }^{2}$, \\ C. O. Костерін ${ }^{1}$
}

${ }^{1}$ Інститут біохімії ім. О. В. Палладіна НАН України, Київ; e-mail: labyntseva@biochem.kiev.ua;

${ }^{2}$ Інститут органічної хімії НАН України, Київ;

Каліксарени - це чашоподібні макроциклічні (поліфенольні) сполуки, вони розглядаються як перспективні молекулярні «платформи» для дизайну нових фізіологічно активних сполук. Раніше в дослідах in vitro нами було виявлено, що калікс[4]арен С-99 інгібує АТРазну активність актоміозину та субфрагмента-1 міозину матки свині. Метою цієї роботи було дослідження взаємодії калікс[4]арену C-99 iз міозином міоцитів матки щура. Для цього досліджувані клітини попередньо інкубували зі 100 мМ калікс[4]ареном C-99, із досліджуваних та контрольних (без каліксарену) міоцитів одержували міозин та визначали його АТРазну активність. Виявилось, що активність АТРази міозину, одержаного з дослідних міоцитів, майже на 50\% нижче порівняно з міозином контрольних клітин. Методом конфокальної мікроскопії показано відмінності (порівняно 3 контролем) у субклітинному розподілі міозину та актину в міоцитах матки, інкубованих із калікс[4]ареном C-99. Ця відмінність може бути обумовлена перебудовами у структурі скоротливих протеїнів гладеньком'язових клітин внаслідок їх взаємодії з каліксареном. Одержані результати свідчать про здатність калікс[4]арену С-99 проникати всередину міоцитів матки та впливати не тільки на АТРазну активність міозину, але й на структуру актинових та міозинових філаментів клітин міометрія. Властивість калікс[4]арену C-99 проникати всередину міоцитів може бути використана в подальшому для розробки нових фармакологічних засобів, здатних ефективно нормалізувати скоротливу гіперфункцію міометрія.

К л ю ч о в і с л о в а: міозин, актин, міоцити міометрія, АТРазна активність, калікс[4]арен С-99, конфокальная мікроскопія.

\section{КАЛИКС[4]АРЕН С-99 ИНГИБИРУЕТ АТРазНую АКТИВНОСТЬ МИОЗИНА И ИЗМЕНЯЕТ СТРУКТУРНУЮ ОРГАНИЗАЦИЮ СОКРАТИТЕЛЬНЫХ ФИЛАМЕНТОВ МИОМЕТРИЯ}

\author{
Р. Д. Лабыниева ${ }^{1}$ А. А. Бевза ${ }^{1}$ А. А. Люлько ${ }^{1}$, \\ С. А. Черенок ${ }^{2}$ В. И. Кальченко ${ }^{2}$, \\ C. A. Костерин ${ }^{1}$ \\ ${ }^{1}$ Институт биохимии им. А. В. Палладина \\ НАН Украины, Киев; \\ e-mail: labyntseva@biochem.kiev.ua; \\ ${ }^{2}$ Институт органической химии \\ НАН Украины, Киев;
}

Каликсарены - чашевидные макроциклические (полифенольные) соединения, которые рассматриваются как перспективные молекулярные «платформы» для дизайна новых физиологически активных соединений. Ранее в опытах in vitro нами было обнаружено, что каликс[4]арен C-99 ингибирует АТРазную активность актомиозина и субфрагмента-1 миозина матки свиньи. Целью настоящей работы было исследование взаимодействия каликс[4]арена C-99 с миозином миоцитов матки крысы. Для этого исследуемые клетки предварительно инкубировали с 100 мМ каликс[4]ареном С-99, из опытных и контрольных (без каликсарена) миоцитов получали миозин и определяли его 
АТРазную активность. Оказалось, что активность АТРазы миозина, полученного из опытных миоцитов, почти на $50 \%$ ниже по сравнению с миозином контрольных клеток. Методом конфокальной микроскопии выявлены различия (по сравнению с контролем) в субклеточном распределении миозина и актина в миоцитах матки, инкубированных с каликс[4]ареном С-99. Это различие может быть обусловлено перестройками в структуре сократительных протеинов гладкомышечных клеток вследствие их взаимодействия с каликсареном. Полученные результаты свидетельствуют о способности каликс[4]арена C-99 проникать внутрь миоцитов матки и влиять не только на АТРазную активность миозина, но и на структуру актиновых и миозиновых филаментов клеток миометрия. Свойство каликс[4]арена С-99 проникать внутрь миоцитов может быть использовано в дальнейшем при разработке новых фармакологических средств, способных эффективно нормализовать сократительную гиперфункцию миометрия.

К лючевы е слова: миозин, актин, миоциты миометрия, АТРазная активность, каликс[4]арен С-99, конфокальная микроскопия.

\section{References}

1. Yilmaz M., Erdemir S. Calix[4]arene-based receptors for molecular recognition. Turk. J. Chem. 2013; 37: 558-585. doi:10.3906/kim-13031305.

2. Rodik R. V., Boyko V. I., Kalchenko V. I. Calix[4]arenes in bio-medical researches. Curr. Med. Chem. 2009; 16(13): 1630-1655.

3. Bevza A. A., Labyntseva R. D., Cherenok S. O., Kalchenko V. I., Kosterin S. O. Kinetic regularities and mechanisms of action of calix[4]arene C-99 on ATPase activity of myosin subfragment-1 of myometrium. Ukr. Biokhim. Zhurn. 2010; 82(6): 22-32.

4. Labyntseva R. D., Slinchenko N. M., Veklich T. O., Rodik R. V, Cherenok S. O., Boiko V. I., Kalchenko V. I., Kosterin S. O. Comparative investigation of calix[4]arenes influence on $\mathrm{Mg}^{2+}$-dependent ATP hydrolase enzymatic systems from smooth muscle cells of the uterus. Ukr. Biokhim. Zhurn. 2007; 79(3): 44-54.
5. Gangula P. R., Dong Y.-L., Yallampalli C. Rat myometrial smooth muscle cells express endothelial nitric oxide synthase. Human Reproduction. 1997; 12(3): 561-568.

6. Chamley-Campbell J., Campbell G. R., Ross R. The smooth muscle cell in culture. Physiol. Rev. 1979; 59(1): 1-61.

7. Skalli O., Ropraz P., Trzeciak A., Benzonana G., Gillessen D., Gabbiani G. A monoclonal antibody against alpha-smooth muscle actin: a new probe for smooth muscle differentiation. $J$. Cell. Biol. 1986; 103(6): 2787-2796.

8. Vadivelu R. K., Yeap S. K., Ali A. M., Hamid M., Alitheen N. B. Betulinic acid inhibits growth of cultured vascular smooth muscle cells in vitro by inducing G1 arrest and apoptosis. Evid. Based Complement. Alternat. Med. 2012; 2012: 251362.

9. Laemmly U. K. Cleavage of structural proteins during the assembly of the head of the bacteriophage T4. Nature (London). 1970; 227(5259): 680-685.

10. Chen P. S., Toribara T. Y., Warner H. Microdetermination of phosphorus. Analyt. Chem. 1956; 28(11): 1756-1758.

11. Lalor R., Baillie-Johnson H., Redshaw C., Matthews S. E., Mueller A. Cellular uptake of a fluorescent calix[4]arene derivative. J. Am. Chem. Soc. 2008; 130(10): 2892-2893.

12. Mueller A., Lalor R., Cardaba C. M., Matthews S. E. Stable and sensitive probes for lysosomes: cell-penetrating fuorescent calix[4]arenes accumulated in acidic vesicle. Cytometry A. 2011;79(2): 126-136.

13. Li C., Fultz M. E., Parkash J., Rhoten W. B., Wright G. L. $\mathrm{Ca}^{2+}$-dependent actin remodeling in the contracting A7r5 cell. J. Muscle Res. Cell Motil. 2001; 22(6): 521-534.

14. Thatcher S. E., Fultz M. E., Tanaka H., Hagiwara H., Zhang H. L., Zhang Y., Hayakawa K., Yoshiyama S., Nakamura A., Wang H. H., Katayama T., Watanabe M., Lin Y., Wright G. L., Kohama K. Myosin light chain kinase/actin interaction in phorbol dibutyratestimulated smooth muscle cells. J. Pharmacol. Sci. 2011; 116(1): 116-127.

Received 14.07.2015 